\title{
Soft tissue coverage of cranial defects: an update
}

\author{
Gabriela L. Lilly ${ }^{1}$, Nicole M. Santucci', Daniel Petrisor ${ }^{2}$, Mark K. Wax \\ 1'Department of Otolaryngology-Head and Neck Surgery, Oregon Health and Science University, Portland, OR 97239, USA. \\ ${ }^{2}$ Department of Oral and Maxillofacial Surgery, OHSU School of Dentistry, Portland, OR 97239, USA. \\ Correspondence to: Dr. Mark K. Wax, Department of Otolaryngology-Head and Neck Surgery, Oregon Health and Science \\ University, 3181 SW Sam Jackson Park Rd PV-01, Portland, OR 97239, USA. E-mail: waxm@ohsu.edu \\ How to cite this article: Lilly GL, Santucci NM, Petrisor D, Wax MK. Soft tissue coverage of cranial defects: an update. Plast \\ Aesthet Res 2021;8:24. https://dx.doi.org/10.20517/2347-9264.2021.21
}

Received: 8 Mar 2021 First Decision: 20 Mar 2021 Revised: 6 Apr 2021 Accepted: 13 Apr 2021 Published: 8 May 2021

Academic Editor: Matthew Spector Copy Editor: Xi-Jun Chen Production Editor: Xi-Jun Chen

\begin{abstract}
Scalp and cranial defects can occur as a result of cutaneous or bony malignancies, trauma, or surgical intervention for intracranial tumors. Soft tissue cranial reconstruction of composite defects presents a unique challenge given the relative tissue inelasticity of the scalp, need for tension free closure, and convex shape of the cranium. An added complexity is found in patients with large defects, cerebrospinal fluid leak, prior failed reconstruction, infection, or previous radiation. Methods and materials for skull reconstruction have evolved significantly over the years, allowing surgeons to repair even the most challenging composite defects with excellent success rates. This review aims to discuss and evaluate the available soft tissue options for cranioplasty coverage, with particular focus on hostile reconstructive fields and the use of free tissue transfer.
\end{abstract}

Keywords: Cranioplasty, free flap reconstruction, scalp defect

\section{INTRODUCTION}

Scalp and cranial defects can occur as a result of cutaneous or bony malignancies, trauma, or surgical intervention for intracranial tumors. Cranial reconstruction is critical to ensuring adequate protection and coverage of the brain and cerebrospinal fluid (CSF) space, with the soft tissue component providing protection of the native calvarium or the alloplastic materials used to replace the cranium. Soft tissue cranial reconstruction presents a unique challenge given the relative tissue inelasticity of the scalp, need for tension-free closure, and convex shape of the cranium ${ }^{[1-5]}$. An added complexity is found in patients with 
large defects, CSF leak, prior failed reconstruction, infection, or previous radiation ${ }^{[2,4,6-8]}$. In these cases, the reconstructive field is particularly hostile due to poor vascularity, presence of biofilm on the implanted cranioplasty, and radio-necrosis of the remaining skull with associated chronic infection. The increased incidence of scalp tumors seen as the population ages has increased the number of elderly patients that have had multiple previous treatments with a resultant hostile reconstructive bed [Figure 1]. Methods and materials for skull reconstruction have evolved significantly over the years, allowing surgeons to repair even the most challenging composite defects with excellent success rates. Previous materials such as calcium hydroxyapatite and methyl methacrylate are rarely used in today's reconstructive environment. They have been replaced with titanium mesh and 3D-modeled synthetic materials. This review aims to discuss and evaluate the available soft tissue options for cranioplasty coverage, with particular focus on hostile reconstructive fields and the use of free tissue transfer. A contemporary comparison of the tissues available will be presented.

\section{THE RECONSTRUCTIVE QUIVER}

\section{Secondary intention}

As with soft tissue defects elsewhere on the body, the reconstructive surgeon has a number of different techniques at their disposal for repair of the defect. The method used should take into account the underlying soft and hard tissue structures that need to be reconstructed, prior surgical and adjuvant therapy, need for adjuvant therapy postoperatively, and the available soft tissue envelope adjacent to the defect. Healing by secondary intention is a viable option for soft-tissue only scalp defects, especially in the case of partial thickness. Healing can be long, requiring consistent wound care. The complexity of the defect, the support structure of the patient and the underlying pathology should be considered when using this modality. It cannot be applied to coverage of cranioplasty as long-term exposure of the alloplastic material or bone flap will predispose to infection and CSF leak ${ }^{[9]}$. When a cranioplasty has been performed and local flaps have been used for cranioplasty coverage, then the defect resulting from rotation of the local flap can be allowed to granulate and heal by secondary intention. When periosteum overlying the native scalp is left intact, the healing process will be quick and efficient ${ }^{[9-11]}$. If periosteum has been removed from the bone, some authors will drill the bone down to the cancellous layer to facilitate granulation tissue formation. Healing can take longer in this circumstance. Disadvantages of healing by secondary intention include longer healing time, contour mismatch, alopecia, and scar contracture ${ }^{[9-11]}$ [Figure 2].

\section{Primary closure and tissue expanders}

Primary closure is challenging in scalp reconstruction due to the skin and subcutaneous soft tissue adherence to the inelastic galea aponeurotica and the location of scalp vasculature between these two layers. Significant undermining must be undertaken for appropriate mobility, which must occur in a sub-galeal plane so as to avoid vascular compromise to the overlying skin. Depending on the location of the defect, this can affect position of critical facial structures such as the hairline and brows. Thus, a simple primary closure is typically appropriate for defects less than $2-3 \mathrm{~cm}$ in size $\mathrm{s}^{[1,2,4,9,10,12-14]}$. Its success depends entirely on tensionfree closure, which can be achieved by galeal releasing incisions made parallel to the area of closure $e^{[9,10]}$. The advantages of this method include short operative time and ease of site monitoring for tumor recurrence. It bears the risk of wound breakdown and associated cranioplasty implant exposure, particularly if postoperative radiation is required, and is often avoided in patients with preoperative soft tissue compromise - such as chronic infection, preoperative radiation, or multiple prior surgeries. In these patients a tension-free closure is essential, otherwise ancillary measures need to be employed.

Tissue expansion, by where the scalp soft tissues are progressively stretched using an expander in the subgaleal plane, can be used as an adjunct to primary closure in larger defects, with generally good cosmetic results ${ }^{[2,4,5,7]}$. It has the benefit of minimizing scalp incisions and associated scarring, as well as maintaining 


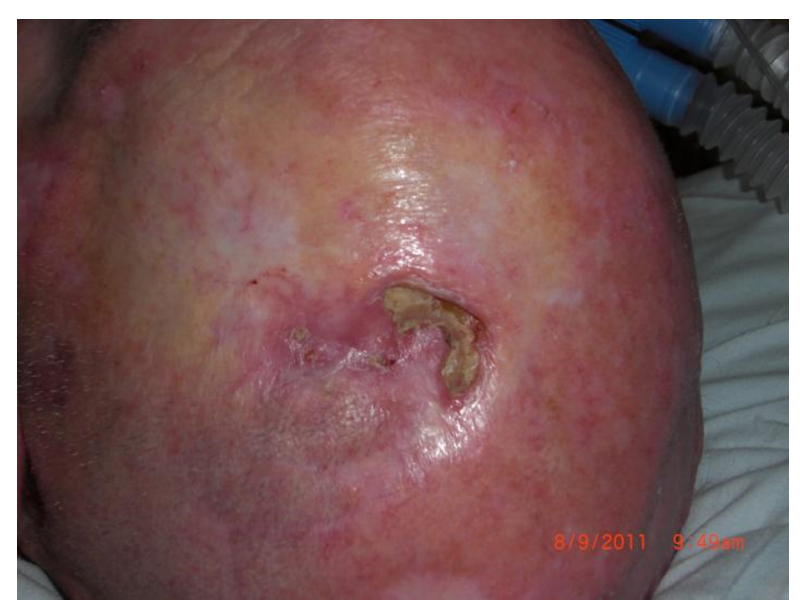

Figure 1. This patient has had previous surgical resection and radiation and now has necrotic bone exposed. They will require craniectomy with a cranioplasty and soft tissue coverage.

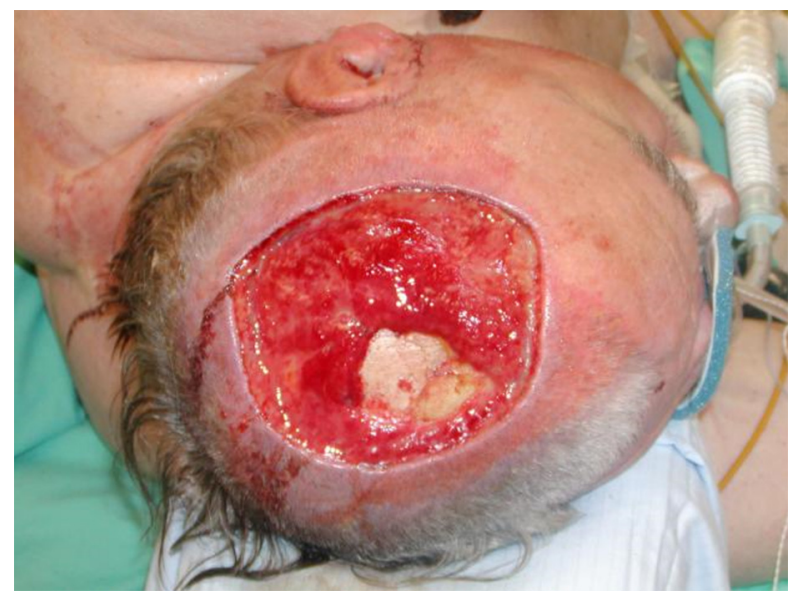

Figure 2. A large skull defect with exposed cranial bone was left to granulate. After greater than 6 weeks, while there has been significant granulation tissue, wound healing is prolonged. Pain and constant care prompted the patient to seek an alternative.

hear-bearing skin on the scalp ${ }^{[4,12]}$. The overall complication rate is approximately $20 \%$, and the most commonly observed complications are wound infection, implant exposure or rupture, and peri-implant hematoma formation ${ }^{[4,15]}$. Preoperative estimates of the size of the bony and soft tissue defects are required, and careful consideration must be given to the degree of convexity of the underlying skull, which can significantly impact the amount of expansion needed ${ }^{[4]}$. This technique can take weeks to months, so it is not a practical solution in oncologic or trauma cases, where timely cranioplasty coverage is indicated. It is typically avoided if greater than $50 \%$ of the scalp is resected, if there is active osteomyelitis, or under irradiated skin (due to the risk for vascular compromise and soft tissue necrosis) $)^{[1,11]}$.

\section{Local and regional flap reconstruction}

Local flap reconstruction is an effective option for scalp defects that are less than $100 \mathrm{~cm}^{2}$, which employs the general principles of rotation, transposition, and advancement ${ }^{[5,16-18]}$. Local flaps are ideally planned as large wide-based flaps with an axial blood supply, which is based around one or more of the five paired major arteries to the scalp (supratrochlear, supraorbital, superficial temporal, postauricular, and occipital $)^{[11]}$. There are many variations of local flap reconstructions described in the literature, and often a 
combination of rotation and advancement flaps are used in order to redistribute closure-related tension over a wider area of the scalp ${ }^{[10,19,20]}$. Care is undertaken to distribute incisions away from the underlying cranioplasty if possible, and to preserve the existing hairline and brow position. Presence of any tension on the suture line overlying a cranioplasty will make it more likely to break down than the same suture line tension over the native cranium. Breakdown of the incision over a cranioplasty at a minimum requires reoperation to close the defect, which unfortunately often results in cranioplasty explanting and further reconstructive surgery. Common examples of local flaps include bilateral opposing rotational flaps (O-Z), 3armed or 4-armed pinwheel flaps, and the Ortichoa flap, which is employed for medium to large defects. The complication rate is approximately $3 \%-4 \%$, and includes incisional alopecia and necrosis of the distal aspect of the flap ${ }^{[9-11]}$. Local flaps have less flexibility in positioning and orientation compared to free flaps ${ }^{[1,8]}$, and are seldom used if the donor scalp skin has been radiated due to the risk of devascularization and subsequent wound breakdown ${ }^{[1,21]}$ [Figure 3A-D].

Regional flaps, such as the pectoralis major flap, lower island trapezius flap, and latissimus dorsi pedicled flap, have limited indications for use in scalp reconstruction, particularly with the advent of free tissue transfer. They carry the benefit of bringing a large amount of healthy tissue into the surgical field, but are limited by their ability to reach most scalp defects. Given their bulk and weight, they are plagued by a gravitational pull of the flap toward its pedicle, with associated ischemia of their distal tip ${ }^{[9-11]}$.

\section{Skin grafting and dermal regeneration templates}

Split and full thickness skin grafts (STSG, FTSG) initially rely on plasmatic inhibition, in which graft survival depends on absorption of nutrients from the wound bed ${ }^{[11]}$. Thus, in scalp reconstruction, they are generally used only when the pericranium, which carries its own blood supply, is left intact. When pericranium cannot be left intact, a large pericranial flap or sub-galeal fascial flap can be rotated into the defect and a skin graft placed over this in the same procedure ${ }^{[5,22,23]}$. Alternatively, the outer cortex of the skull can be burred down, exposing blood supply for the grafted skin within the diploic space ${ }^{[24]}$. In this case, better outcomes have been reported with the use of full-thickness skin grafts, although this is controversial ${ }^{[25]}$. Given their reliance on the underlying vascular supply, skin grafts cannot be used to cover cranioplasty sites. They are employed successfully, however, for coverage of scalp donor sites when local advancement or rotation flaps are used for cranioplasty coverage ${ }^{[25]}$. The disadvantages of this technique include alopecia at the defect site, contour deformities, hypopigmentation, and thin/tenuous coverage of the scalp, which limits their use if cosmesis is a concern or postoperative radiation is required ${ }^{[\rho]}$. Given the thin and tenuous skin, any form of trauma will leave a wound that needs to heal by secondary intention. Furthermore, patients that have had prior radiation to the scalp tend not to heal split-thickness skin grafts very well [Figure 4].

Dermal regeneration templates (DRT), such as Integra, are both a complement and alternative to skin grafting, which were first used in 1981 by Yannas and Burke to combat fluid loss and infection in patients with extensive skin loss following burn injury ${ }^{[26-28]}$. They are composed of a bovine collagen and glycosaminoglycan-based skin substitute with a thin silicone outer protective layer ${ }^{[27,29]}$. Traditionally, DRTs have been used in a staged approach to scalp reconstruction, whereby a DRT is first placed to encourage neovascularization and host cell migration, and is followed by placement of a STSG within 3-6 weeks, once a neodermis has formed ${ }^{[2,28,30-34]}$. Recent reports have also found success with concomitant use in a singlestage reconstruction ${ }^{[35]}$. This method delivers positive aesthetic and functional results with fewer adhesions and wound contractures than STSG alone ${ }^{[31,36]}$, which has been shown to be effective for large scalp defects $\left(>100 \mathrm{~cm}^{2}\right)$, where skin grafting or local flap reconstruction outcomes are limited ${ }^{[2,32]}$. Given its low morbidity, this approach is particularly useful in patients with complex medical comorbidities where microvascular surgery is not an option but cosmesis is a concern ${ }^{[29,30,32,34]}$. Once again, this cannot be reliably 

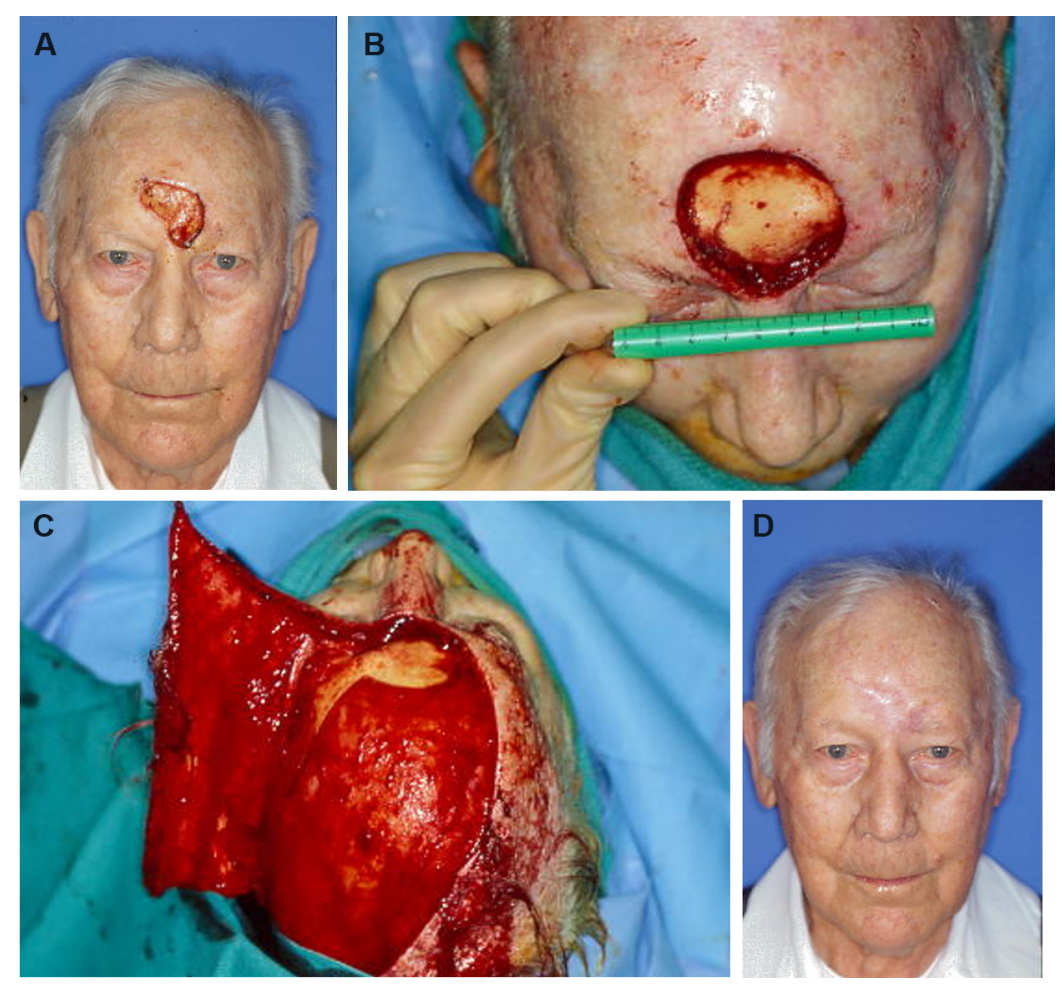

Figure 3. This patient has a nonhealing wound of the forehead and scalp (A). It has been excised for clear margins he has had previous radiation (B). A large rotation advancement flap was utilized (C). An acceptable cosmetic and functional outcome is acquired (D).

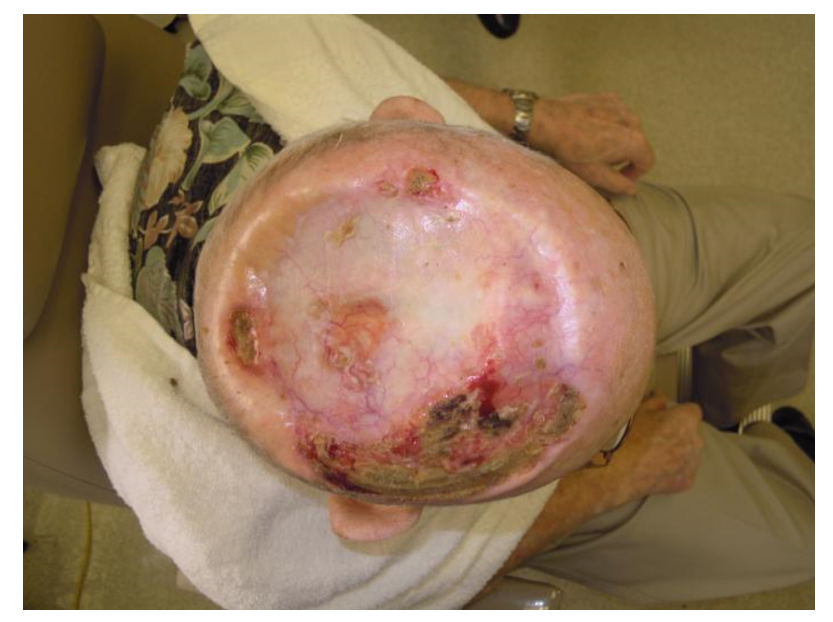

Figure 4. This patient had a large split-thickness skin graft for reconstruction of a significant scalp defect. He has chronic continuous healing issues due to the thinness of the tissue and its tendency to be abraded.

used over an alloplastic cranioplasty, but proves effective for coverage of a donor scalp defect when local flaps are used in cranioplasty coverage. Their use in a right radiated field is not well described.

\section{FREE TISSUE TRANSFER AND 3D MODELING}

Free tissue transfer is the preferred method described in the literature for coverage of large defects (greater than $100-200 \mathrm{~cm}^{2}$ ) or rehabilitation of hostile defects, namely those exhibiting chronic infection, persistent 
CSF leak, prior failed reconstructions, or prior radiation ${ }^{[10,11,37-40]}$. It carries the advantage of bringing a large amount of well vascularized, non-radiated tissue into the surgical bed, and allows for a tension-free closure without reliance on the variable axial blood supply of local flaps ${ }^{[0,38]}$. The pliability and thickness of the transplanted tissue allow it to contour to the underlying tissue and withstand postoperative radiation with reduced risk of wound healing complications ${ }^{[11]}$. Success rates of free tissue transfer for cranioplasty coverage have been reported over 95\%, with well tolerated coverage and acceptable cosmetic results ${ }^{[41-44]}$.

A variety of free flaps have been described for cranioplasty coverage, performed both as immediate and staged reconstructions $s^{[1,9-11,19,21,37,38,41-45]}$. These can be categorized as myofascial (latissimus dorsi, anterolateral thigh, and rectus abdominis), myocutaneous (the same flaps harvested with overlying skin), fasciocutaneous (radial forearm, and anterolateral thigh without associated muscle), and osteocutaneous or osteomyocutaneous (osteocutaneous radial forearm, scapular flap, fibular flap, and latissimus dorsi with underlying rib) [Table 1]. No clear consensus exists on which type of flap provides superior outcomes, with conflicting reports in the literature that are often based on a small number of cases from a single institution. Vargo et al. ${ }^{[46]}$, in a study of 45 microvascular flaps performed for cranioplasty coverage, found that myofascial flaps covered with skin grafts yielded the lowest short and long-term complication rate, while fasciocutaneous flaps yielded the highest. These included partial flap loss, wound dehiscence, and infected cranioplasty. Myocutaneous flaps tended to have higher complications than myofascial in this study population. Chao et al. ${ }^{[42]}$, in a study of 48 scalp reconstructions involving concurrent cranioplasty found no difference in postoperative outcomes between myofascial and fasciocutaneous/myocutaneous free flap reconstruction. Uzun et al. ${ }^{[4]}$, when examining 21 free flap reconstructions for cranioplasty coverage, found no difference in postoperative outcomes between fasciocutaneous and myocutaneous free tissue transfer, although the former had the benefits of shorter hospitalization and lower rates of tissue atrophy. These findings corroborated prior results reported by Sweeny et al. ${ }^{[1]}$ [Figure $\left.5 \mathrm{~A}-\mathrm{C}\right]$.

The timing of soft tissue and bony reconstruction has also been under debate. Previous studies have described soft tissue only reconstruction of composite defects, with the potential for delayed bony reconstruction depending on healing outcomes ${ }^{[46,48}$. However, this approach leaves patients vulnerable to cerebral injury and development of the syndrome of the trephined, in which soft-tissue sinking over time leads to neurological dysfunction including cognitive, motor and language deficits ${ }^{[46]}$. Vargo et al. ${ }^{[46]}$, in their study of 45 flap reconstructions, found significantly higher wound complication rates with immediate reconstructions as compared to delayed, but only if alloplastic cranioplasty material was used. Chao et al. ${ }^{[42]}$, when comparing composite cranial and soft tissue reconstruction to scalp reconstruction alone, found no significant difference in postoperative complications when immediate skull reconstruction was also performed. Their study, however, did not compare delayed or no cranioplasty to simultaneous reconstructions, and reported a fairly high complication rate of $29.2 \%$. Kwiecien et al. ${ }^{[48]}$, when evaluating re-infection rates of alloplastic cranioplasties performed for chronic cranial osteomyelitis, found a significantly higher rate if cranioplasties were performed earlier than 3 months after resection as compared to 1 year after resection. Given that perioperative radiation has been shown to be an independent predictor of post-free tissue transfer wound breakdown and associated infection ${ }^{[4]}$, many authors advise proceeding with caution if performing an alloplastic cranial reconstruction at the time of free tissue transfer in a previously radiated or infected surgical field ${ }^{[42,46,48,50]}$.

As described above, the cranioplasty material used varies widely and can significantly impact the long-term success of free tissue transfer for scalp reconstruction. Calvarial reconstructive options include autologous bone (which can be in the form of a stored cranial bone flap, or an osteocutaneous or osteomyocutaneous free flap) or alloplastic materials, including titanium mesh, polyetheretherketone (PEEK), polymethyl 
Table 1. Comparison of free tissue transfer options in coverage of cranioplasty defects

\begin{tabular}{|c|c|c|c|c|c|c|}
\hline $\begin{array}{l}\text { Free tissue } \\
\text { transfer } \\
\text { option }\end{array}$ & Flap type & Advantages & Disadvantages & $\begin{array}{l}\text { Pedicle } \\
\text { length }\end{array}$ & $\begin{array}{l}\text { Typical recipient } \\
\text { vessels used }\end{array}$ & $\begin{array}{l}\text { Techniques for achieving } \\
\text { further length }\end{array}$ \\
\hline $\begin{array}{l}\text { Latissimus } \\
\text { dorsi }\end{array}$ & $\begin{array}{l}\text { Myocutaneous, myogenous, } \\
\text { or osteomyocutaneous with } \\
\text { harvest of underlying rib }\end{array}$ & $\begin{array}{l}\text { Large muscle/soft tissue harvest options } \\
(20-40 \mathrm{~cm}) \text {, low donor site morbidity }\end{array}$ & $\begin{array}{l}\text { Very bulky, with associated cosmetic } \\
\text { implications, cannot always be } \\
\text { harvested concurrent to ablative } \\
\text { procedure }\end{array}$ & $5-15 \mathrm{~cm}$ & $\begin{array}{l}\text { Superficial temporal } \\
\text { artery and vein, can } \\
\text { reach external } \\
\text { carotid system if } \\
\text { needed }\end{array}$ & $\begin{array}{l}\text { Carefully dissect the subscapular } \\
\text { artery system at the level of the } \\
\text { axilla, ligating the serratus } \\
\text { anterior and circumflex scapular } \\
\text { branches }\end{array}$ \\
\hline $\begin{array}{l}\text { Anterolateral } \\
\text { thigh }\end{array}$ & $\begin{array}{l}\text { Fasciocutaneous, } \\
\text { myocutaneous or myogenous }\end{array}$ & $\begin{array}{l}\text { Large muscle/soft tissue harvest options (up to } \\
25 \mathrm{~cm} \text { ), numerous chimeric flap options, flexibility in } \\
\text { amount of bulk harvested, fascia lata can be } \\
\text { concurrently harvested to reconstruct dura, low } \\
\text { donor site morbidity, can be harvested during } \\
\text { ablative procedure }\end{array}$ & $\begin{array}{l}\text { Brings hair-bearing skin with it, which } \\
\text { can be cosmetically unappealing in } \\
\text { some circumstance }\end{array}$ & $8-12 \mathrm{~cm}$ & $\begin{array}{l}\text { Superficial temporal } \\
\text { artery and vein }\end{array}$ & $\begin{array}{l}\text { Raise pedicle to include distal } \\
\text { aspect of the descending branch } \\
\text { of lateral circumflex femoral } \\
\text { artery or part of the profunda } \\
\text { femoris }\end{array}$ \\
\hline $\begin{array}{l}\text { Rectus } \\
\text { abdominis }\end{array}$ & Myocutaneous or myogenous & $\begin{array}{l}\text { Large muscle/soft tissue harvest options }(10 \times 30 \\
\mathrm{cm} \text { of muscle), can be harvested during ablative } \\
\text { procedure }\end{array}$ & Moderate donor site morbidity & $5-7 \mathrm{~cm}$ & $\begin{array}{l}\text { Superficial temporal } \\
\text { artery and vein }\end{array}$ & $\begin{array}{l}\text { Increase intramuscular dissection } \\
\text { of the inferior epigastric artery }\end{array}$ \\
\hline Radial forearm & $\begin{array}{l}\text { Fasciocutaneous or } \\
\text { osteocutaneous }\end{array}$ & $\begin{array}{l}\text { Large cutaneous surface area can be harvested, can } \\
\text { be harvested during ablative procedure }\end{array}$ & $\begin{array}{l}\text { Thin skin/no bulk, small amt of bone } \\
(8-10 \mathrm{~cm}) \text { with single osteotomy } \\
\text { available }\end{array}$ & Up to $15 \mathrm{~cm}$ & $\begin{array}{l}\text { Superficial temporal } \\
\text { artery and vein, can } \\
\text { reach external } \\
\text { carotid system if } \\
\text { needed }\end{array}$ & $\begin{array}{l}\text { Dissect up to takeoff from } \\
\text { brachial artery }\end{array}$ \\
\hline Scapular flap & $\begin{array}{l}\text { Osteocutaneous or } \\
\text { osteomyocutaneous }\end{array}$ & $\begin{array}{l}\text { Large soft tissue harvest options }(10-25 \mathrm{~cm}) \text {, can } \\
\text { combine with latissimus dorsi flap, low donor site } \\
\text { morbidity }\end{array}$ & $\begin{array}{l}\text { Small amt of thin bone }(10-12 \mathrm{~cm}) \\
\text { with single osteotomy available, } \\
\text { potentially difficult to harvest during } \\
\text { ablative procedure thus increased OR } \\
\text { time }\end{array}$ & $3-7 \mathrm{~cm}$ & $\begin{array}{l}\text { Superficial temporal } \\
\text { artery and vein }\end{array}$ & $\begin{array}{l}\text { Take flap based on the angular } \\
\text { scapula branch from the } \\
\text { thoracodorsal artery, which can } \\
\text { arise from the serratus artery or } \\
\text { subscapular artery }\end{array}$ \\
\hline Fibular flap & Osteocutaneous & $\begin{array}{l}\text { Excellent vascular supply, large amount of thick } \\
\text { bone }(25 \mathrm{~cm}) \text { with multiple osteotomies possible, } \\
\text { low donor site morbidity, can be harvested during } \\
\text { ablative procedure }\end{array}$ & Unable to provide bulk & Up to $15 \mathrm{~cm}$ & $\begin{array}{l}\text { Superficial temporal } \\
\text { artery and vein, can } \\
\text { reach external } \\
\text { carotid system if } \\
\text { needed }\end{array}$ & $\begin{array}{l}\text { Dissect peroneal artery and its } \\
\text { venae from the fibula and use } \\
\text { distal aspect of bone for } \\
\text { reconstruction }\end{array}$ \\
\hline
\end{tabular}

methacrylate (PMMA), or hydroxyapatite (HA). Liu et al. ${ }^{[1]]}$ recently published a meta-analysis comparing postoperative complication rates between these materials. In their review of 20 articles inclusive of 2913 patients, they found overall higher complication rates with the use of autogenous bone when compared to alloplastic bone substitute. The most common complication of autologous bone was resorption, followed closely by infection and hematoma. This does not appear to be the case if vascularized bone is used, however, regardless of the timing of reconstruction or the hostility of the defect ${ }^{[52}$. Of the alloplastic materials, PEEK yielded the lowest overall complication rates, particularly in terms of long-term implant exposure, but continued to carry equally high postoperative infection rates ${ }^{[51]}$. HA, while highly biocompatible, carries a high risk of fracture, and is thus limited to smaller defects ${ }^{[51]}$. Titanium mesh has 

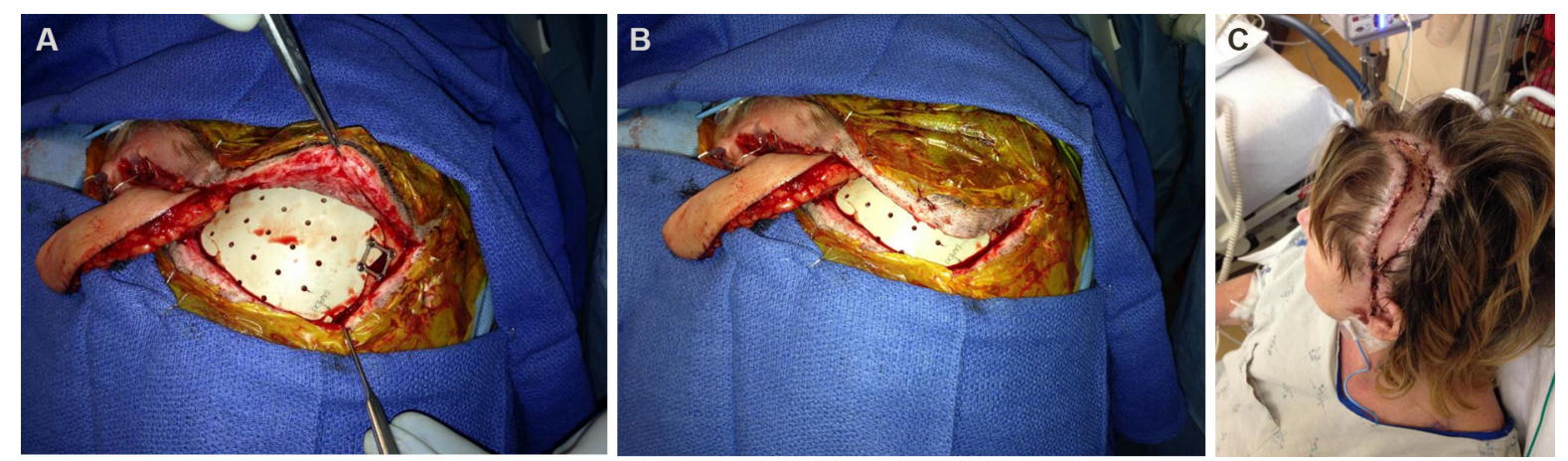

Figure 5. Patient with multiple previous surgical procedures and radiation therapy developed an exposed cranioplasty (A). A radial forearm flap was utilized to provide coverage (B). The alopecia is well masked by hair from other areas (C).
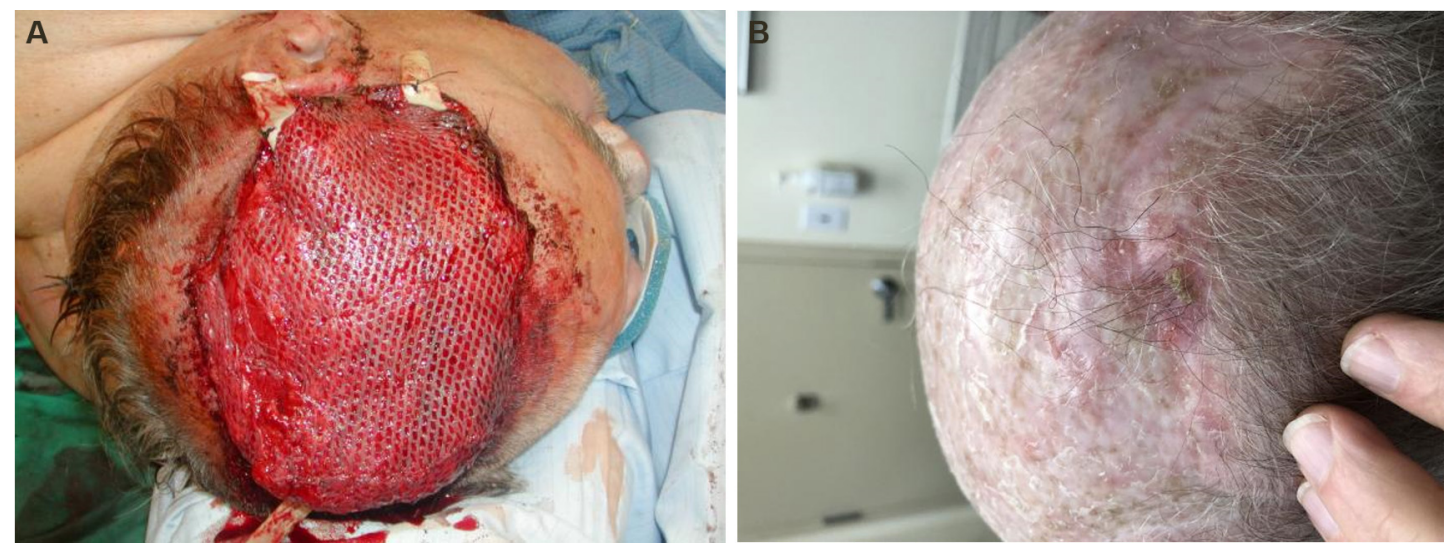

Figure 6. A mesh cranioplasty has been covered by a latissimus dorsi myelogenous free flap (A). One year later the cosmetic result is acceptable (B).

been found to be associated with a higher rate of implant exposure ${ }^{[50,53]}$, while PMMA carries the highest risk of postoperative infection ${ }^{[53]}$.

Furthermore, decreased complication rates have been seen with the use of custom implants and 3D stereolithographic model for surgical planning, particularly in extremely complicated cases and hostile reconstructive environments ${ }^{[5]}$. The use of CAD/CAM computerized modeling has allowed the reconstructive/neuro-surgeon to design and synthesize an implant that has the desired volume and a 3dimensional similarity to the calvarial bone. This cranioplasty implant can be made to fit any particular defect and fit extremely well, with little modifications needed. This decreases operative time, improves cosmesis, and has lower associated infection and failure rates as compared to traditional cranioplasty techniques ${ }^{[5,56]}$. In a hostile bed, the addition of a free myogenous flap brings in healthy vascularized tissue that allows for a further decrease in the potential infection and extrusion of these implants [Figure $6 \mathrm{~A}$ and $\mathrm{B}]$.

\section{CONCLUSION}

Successful reconstruction of composite cranial defects remains a challenge, owing to high rates of postoperative wound breakdown, with the risk of associated infection and CSF leak. Several algorithms have been proposed to guide reconstructions, focusing on defect size, depth, and on the hostility of the reconstructed environment. Primary closure, skin grafting, and local flap reconstruction are excellent 
options for small defects in the absence of chronic infection or perioperative radiation. However, larger defects or associated decreased vascularity of the surrounding tissue necessitate free tissue transfer. Larger, multi-institutional studies are required to determine the characteristics of a successful free flap scalp reconstruction, as available evidence is based primarily on small case series. Additionally, multidisciplinary efforts are warranted to evaluate the optimal combined bone and soft tissue reconstructive approach.

\section{DECLARATIONS}

\section{Authors' contributions}

Designed the scope of the review article: Wax MK

Made substantial contributions to writing of the manuscript: Lilly GL, Santucci NM, Wax MK

Contributed to manuscript editing: Lilly GL, Wax MK

\section{Availability of data and materials}

Not applicable.

\section{Financial support and sponsorship}

None.

\section{Conflicts of interest}

All authors declared that there are no conflicts of interest.

\section{Ethical approval and consent to participate}

Not applicable.

\section{Consent for publication}

The study is obtained consent to participate from participants.

\section{Copyright}

(c) The Author(s) 2021.

\section{REFERENCES}

1. Sweeny L, Eby B, Magnuson JS, Carroll WR, Rosenthal EL. Reconstruction of scalp defects with the radial forearm free flap. Head Neck Oncol 2012;4:21. DOI PubMed PMC

2. Newman MI, Hanasono MM, Disa JJ, Cordeiro PG, Mehrara BJ. Scalp reconstruction: a 15-year experience. Ann Plast Surg 2004;52:501-6; discussion 506. DOI PubMed

3. Tolhurst DE, Carstens MH, Greco RJ, Hurwitz DJ. The surgical anatomy of the scalp. Plast Reconstr Surg 1991;87:603-12; discussion 613. PubMed

4. Carloni R, Hersant B, Bosc R, Le Guerinel C, Meningaud JP. Soft tissue expansion and cranioplasty: for which indications? J Craniomaxillofac Surg 2015;43:1409-15. DOI PubMed

5. Leedy JE, Janis JE, Rohrich RJ. Reconstruction of acquired scalp defects: an algorithmic approach. Plast Reconstr Surg 2005;116:54e72e. DOI PubMed

6. Ioannides C, Fossion E, Mcgrouther AD. Reconstruction for large defects of the scalp and cranium. J Craniomaxillofac Surg 1999;27:145-52. DOI PubMed

7. Mundinger GS, Latham K, Friedrich J, et al. Management of the repeatedly dailed cranioplasty following large postdecompressive craniectomy: establishing the efficacy of staged free latissimus dorsi transfer/tissue expansion/custom polyetheretherketone implant reconstruction. J Craniofac Surg 2016;27:1971-7. DOI PubMed

8. Hardesty RA, Jones NF, Swartz WM, et al. Microsurgery for macrodefects: microvascular free-tissue transfer for massive defects of the head and neck. Am J Surg 1987;154:399-405. DOI PubMed

9. Desai SC, Sand JP, Sharon JD, Branham G, Nussenbaum B. Scalp reconstruction: an algorithmic approach and systematic review. JAMA Facial Plast Surg 2015;17:56-66. DOI PubMed

10. Fowler NM, Futran ND. Achievements in scalp reconstruction. Curr Opin Otolaryngol Head Neck Surg 2014;22:127-30. DOI PubMed

11. Bradford BD, Lee JW. Reconstruction of the Forehead and Scalp. Facial Plast Surg Clin North Am 2019;27:85-94. DOI PubMed

12. Lutz BS, Wei FC, Chen HC, Lin CH, Wei CY. Reconstruction of scalp defects with free flaps in 30 cases. Br J Plast Surg 
1998;51:186-90. DOI PubMed

13. Chang KP, Lai CH, Chang CH, Lin CL, Lai CS, Lin SD. Free flap options for reconstruction of complicated scalp and calvarial defects: report of a series of cases and literature review. Microsurgery 2010;30:13-8. DOI PubMed

14. Fong AJ, Lemelman BT, Lam S, Kleiber GM, Reid RR, Gottlieb LJ. Reconstructive approach to hostile cranioplasty: a review of the University of Chicago experience. J Plast Reconstr Aesthet Surg 2015;68:1036-43. DOI PubMed

15. Cunha MS, Nakamoto HA, Herson MR, Faes JC, Gemperli R, Ferreira MC. Tissue expander complications in plastic surgery: a 10year experience. Rev Hosp Clin Fac Med Sao Paulo 2002;57:93-7. DOI PubMed

16. Vecchione TR, Griffith L. Closure of scalp defects by using multiple flaps in a pinwheel design. Plast Reconstr Surg 1978;62:74-7. DOI PubMed

17. Orticochea M. New three-flap scalp reconstruction technique. Br J Plast Surg 1971;24:184-8. DOI PubMed

18. Kroll SS, Margolis R. Scalp flap rotation with primary donor site closure. Ann Plast Surg 1993;30:452-5. DOI PubMed

19. Hoffmann JF. Management of scalp defects. Otolaryngol Clin North Am 2001;34:571-82. DOI PubMed

20. Hwang L, Ford NK, Spitz J, Ellis M. The Visor Flap: A novel design for scalp wound closure. J Craniofac Surg 2017;28:e146-8. DOI PubMed

21. Steiner D, Horch RE, Eyüpoglu I, et al. Reconstruction of composite defects of the scalp and neurocranium-a treatment algorithm from local flaps to combined AV loop free flap reconstruction. World J Surg Oncol 2018;16:217. DOI PubMed PMC

22. Carstens MH, Greco RJ, Hurwitz DJ, Tolhurst DE. Clinical applications of the subgaleal fascia. Plast Reconstr Surg 1991;87:615-26. DOI PubMed

23. Terranova W. The use of periosteal flaps in scalp and forehead reconstruction. Ann Plast Surg 1990;25:450-6. DOI PubMed

24. Molnar JA, DeFranzo AJ, Marks MW. Single-stage approach to skin grafting the exposed skull. Plast Reconstr Surg 2000;105:174-7. DOI PubMed

25. Wolff AY, Santiago GF, Belzberg M, et al. Full-thickness skin grafting for local defect coverage following scalp adjacent tissue transfer in the setting of cranioplasty. J Craniofac Surg 2019;30:115-9. DOI PubMed

26. Burke JF, Yannas IV, Quinby WC Jr, Bondoc CC, Jung WK. Successful use of a physiologically acceptable artificial skin in the treatment of extensive burn injury. Ann Surg 1981;194:413-28. DOI PubMed PMC

27. Heitland A, Piatkowski A, Noah EM, Pallua N. Update on the use of collagen/glycosaminoglycate skin substitute-six years of experiences with artificial skin in 15 German burn centers. Burns 2004;30:471-5. DOI PubMed

28. Yannas IV, Burke JF, Orgill DP, Skrabut EM. Wound tissue can utilize a polymeric template to synthesize a functional extension of skin. Science 1982;215:174-6. DOI PubMed

29. Richardson MA, Lange JP, Jordan JR. Reconstruction of full-thickness scalp defects using a dermal regeneration template. JAMA Facial Plast Surg 2016;18:62-7. DOI PubMed

30. Cordaro ER, Calabrese S, Faini GP, Zanotti B, Verlicchi A, Parodi PC. Method to thicken the scalp in calvarian reconstruction. $J$ Craniofac Surg 2011;22:598-601. DOI PubMed

31. Tufaro AP, Buck DW 2nd, Fischer AC. The use of artificial dermis in the reconstruction of oncologic surgical defects. Plast Reconstr Surg 2007;120:638-46. DOI PubMed

32. Johnson MB, Wong AK. Integra-based reconstruction of large scalp wounds: a case report and systematic review of the literature. Plast Reconstr Surg Glob Open 2016;4:e1074. DOI PubMed PMC

33. Schiavon M, Francescon M, Drigo D, et al. The use of integra dermal regeneration template versus flaps for reconstruction of fullthickness scalp defects involving the calvaria: a cost-benefit analysis. Aesthetic Plast Surg 2016;40:901-7. DOI PubMed PMC

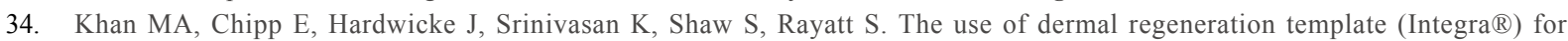
reconstruction of a large full-thickness scalp and calvarial defect with exposed dura. J Plast Reconstr Aesthet Surg 2010;63:2168-71. DOI PubMed

35. Kosutic D, Beasung E, Dempsey M, et al. Single-layer Integra for one-stage reconstruction of scalp defects with exposed bone following full-thickness burn injury: a novel technique. Burns 2012;38:143-5. DOI PubMed

36. Dantzer E, Queruel P, Salinier L, Palmier B, Quinot J. Dermal regeneration template for deep hand burns: clinical utility for both early grafting and reconstructive surgery. Br J Plast Surg 2003;56:764-74. DOI PubMed

37. Yuen JC, Hochberg J. Free flap coverage of scalp defects following radiation. J Ark Med Soc 2003;100:194-5. PubMed

38. Shonka DC Jr, Potash AE, Jameson MJ, Funk GF. Successful reconstruction of scalp and skull defects: lessons learned from a large series. Laryngoscope 2011;121:2305-12. DOI PubMed

39. Wax MK, Kim J, Ducic Y. Update on major reconstruction of the head and neck. Arch Facial Plast Surg 2007;9:392-9. DOI PubMed

40. Cannady SB, Rosenthal EL, Knott PD, Fritz M, Wax MK. Free tissue transfer for head and neck reconstruction: a contemporary review. JAMA Facial Plast Surg 2014;16:367-73. DOI PubMed

41. Beasley NJ, Gilbert RW, Gullane PJ, Brown DH, Irish JC, Neligan PC. Scalp and forehead reconstruction using free revascularized tissue transfer. Arch Facial Plast Surg 2004;6:16-20. DOI PubMed

42. Chao AH, Yu P, Skoracki RJ, Demonte F, Hanasono MM. Microsurgical reconstruction of composite scalp and calvarial defects in patients with cancer: a 10-year experience. Head Neck 2012;34:1759-64. DOI PubMed

43. Fischer JP, Sieber B, Nelson JA, et al. A 15-year experience of complex scalp reconstruction using free tissue transfer-analysis of risk factors for complications. J Reconstr Microsurg 2013;29:89-97. DOI PubMed

44. Wang HT, Erdmann D, Olbrich KC, Friedman AH, Levin LS, Zenn MR. Free flap reconstruction of the scalp and calvaria of major neurosurgical resections in cancer patients: lessons learned closing large, difficult wounds of the dura and skull. Plast Reconstr Surg 2007;119:865-72. DOI PubMed 
45. Seitz IA, Adler N, Odessey E, Reid RR, Gottlieb LJ. Latissimus dorsi/rib intercostal perforator myo-osseocutaneous free flap reconstruction in composite defects of the scalp: case series and review of literature. J Reconstr Microsurg 2009;25:559-67. DOI PubMed

46. Vargo JD, Przylecki W, Andrews BT. Surgical decision-making in microvascular reconstruction of composite scalp and skull defects. J Craniofac Surg 2020;31:1895-9. DOI PubMed

47. Uzun H, Bitik O, Ersoy US, Bilginer B, Aksu AE. Comparison of musculocutaneous and fasciocutaneous free flaps for the reconstruction of the extensive composite scalp and cranium defects. J Craniofac Surg 2018;29:1947-51. DOI PubMed

48. Kwiecien GJ, Aliotta R, Bassiri Gharb B, Gastman B, Zins JE. The timing of alloplastic cranioplasty in the setting of previous osteomyelitis. Plast Reconstr Surg 2019;143:853-61. DOI PubMed

49. Othman S, Azoury SC, Tecce MG, et al. Free flap reconstruction of complex oncologic scalp defects in the setting of mesh cranioplasty: risk factors and outcomes. J Craniofac Surg 2020;31:1107-10. DOI PubMed

50. Kwiecien GJ, Rueda S, Couto RA, et al. Long-term outcomes of cranioplasty: titanium mesh is not a long-term solution in high-risk patients. Ann Plast Surg 2018;81:416-22. DOI PubMed

51. Liu L, Lu ST, Liu AH, et al. Comparison of complications in cranioplasty with various materials: a systematic review and metaanalysis. Br J Neurosurg 2020;34:388-96. DOI PubMed

52. Lee JC, Kleiber GM, Pelletier AT, Reid RR, Gottlieb LJ. Autologous immediate cranioplasty with vascularized bone in high-risk composite cranial defects. Plast Reconstr Surg 2013;132:967-75. DOI PubMed

53. Yeap MC, Tu PH, Liu ZH, et al. Long-term complications of cranioplasty using stored autologous bone graft, three-dimensional polymethyl methacrylate, or titanium mesh after decompressive craniectomy: a single-center experience after 596 procedures. World Neurosurg 2019;128:e841-50. DOI PubMed

54. Wolff A, Santiago GF, Belzberg M, et al. Adult cranioplasty reconstruction with customized cranial implants: preferred technique, timing, and biomaterials. J Craniofac Surg 2018;29:887-94. DOI PubMed

55. Koller M, Rafter D, Shok G, Murphy S, Kiaei S, Samadani U. A retrospective descriptive study of cranioplasty failure rates and contributing factors in novel 3D printed calcium phosphate implants compared to traditional materials. 3D Print Med 2020;6:14. DOI PubMed PMC

56. Ghai S, Sharma Y, Jain N, Satpathy M, Pillai AK. Use of 3-D printing technologies in craniomaxillofacial surgery: a review. Oral Maxillofac Surg 2018;22:249-59. DOI PubMed 